\title{
Petunia vein banding virus: Characterization of a New Tymovirus from Petunia $\times$ hybrida
}

M. A. V. Alexandre, L. M. L. Duarte, E. B. Rivas, C. M. Chagas, and M. M. Barradas, Instituto Biológico, Av. Cons. Rodrigues Alves, 1252, CEP 04014-002, São Paulo, SP, Brazil; and R. Koenig, Biologische Bundesanstalt für Land-und Forstwirtschaft, Institut für Pflanzenvirologie, Mikrobiologie und Biologische Sicherheit, Messeweg 11/12, D-38104, Braunschweig, Germany

\begin{abstract}
Alexandre, M. A. V., Duarte, L. M. L., Rivas, E. B., Chagas, C. M., Barradas, M. M., and Koenig, R. 2000. Petunia vein banding virus: Characterization of a new tymovirus from Petunia $\times$ hybrida. Plant Dis. 84:739-742.

Petunia plants from a nursery in the State of Rio Grande do Sul, Brazil, showed pronounced vein banding and contained isometric particles with diameters of approximately 45 and $30 \mathrm{~nm}$. The larger ones apparently represent a caulimovirus, while the smaller ones, which included both empty shells and full particles, were identified as those of a new tymovirus for which we propose the name Petunia vein banding virus (PetVBV). Originally, PetVBV was transmitted only with difficulty to healthy petunia plants. However, from an experimentally infected petunia, it was later readily transmitted also to Nicotiana benthamiana and Nicandra physalodes, but not to other species in the Solanaceae or other plant families. It produces cytopathic effects typical for tymovirus infections. Its coat protein shows approximately $65 \%$ amino acid sequence identity with those of Eggplant mosaic and Andean potato latent viruses, to which it is also serologically more closely related than to any other tymoviruses.
\end{abstract}

Plants from the genus Petunia are economically important bedding and balcony ornamentals, especially the new hybrids which display intensively colored flowers. In Brazil, two viruses have been reported to infect petunias naturally: a species of the genus Tobamovirus (2) and a putative species of the genus Caulimovirus (3). Plants infected with the latter virus, which has a diameter of approximately $45 \mathrm{~nm}$, also contained smaller particles of about $30 \mathrm{~nm}$ which consisted either of empty protein shells or intact particles (1). They were now identified as those of a new tymovirus for which we propose the name Petunia vein banding virus (PetVBV).

\section{MATERIAL AND METHODS}

Virus source and mechanical transmission. Leaves of Petunia $\times$ hybrida Vilm. with vein banding (Fig. 1) were collected in a government-run nursery at Gramado in the State of Rio Grande do Sul, Brazil. Extracts from infected leaves

Corresponding author: M. A. V. Alexandre

E-mail: alexand@biologico.br

This work was supported in part by a grant from FAPESP. M. A. V. Alexandre and C. M. Chagas hold a fellowship from CNPq.

Accepted for publication 10 March 2000.

Publication no. D-2000-0502-01R

This article is in the public domain and not copyrightable. It may be freely reprinted with customary crediting of the source. The American Phytopathological Society, 2000. were prepared in phosphate buffer $(0.05 \mathrm{M}$, $\mathrm{pH}$ 7.1) and mechanically inoculated on 36 species.

Electron microscopy. Virus particles were visualized after negative staining with $2 \%$ uranyl acetate. For cytological studies, small pieces of healthy or virus-infected leaf tissue were fixed overnight at $4^{\circ} \mathrm{C}$ in $3.0 \%$ glutaraldehyde in $0.1 \mathrm{M}$ phosphate buffer ( $\mathrm{pH} 7.0$ ), postfixed for $2 \mathrm{~h}$ at $4^{\circ} \mathrm{C}$ in $1 \%$ osmium tetroxide in the same buffer, and stained overnight at $4^{\circ} \mathrm{C}$ in $0.5 \%$ uranyl acetate. After dehydration in graded dilutions of acetone, samples were embedded in Spurr's medium, sectioned with an LKB III ultratome, and double stained with uranyl acetate and lead citrate.

Insect transmission. Myzus persicae Sulz., Aphis gossypii Glov., and the chrysomelid beetle Diabrotica speciosa Germ. were tested as possible vectors. The aphids were given acquisition feeding periods of $30 \mathrm{~min}$ on infected petunia plants, then transferred for inoculation feeding for 30 min to 10 healthy plants (10 aphids/plant). In transmission tests with beetles, the acquisition and inoculation feeding times were $48 \mathrm{~h}$.

Purification and antiserum production. The virus was purified by the Triton X-100/urea method of Hull et al. (8). The final purification was by centrifugation through a sucrose density gradient (10 to $40 \%)$ at $35,000 \times g$ for 60 min. Rabbits were immunized by intramuscular or lymphnodal injections of purified virus emulsified with an equal volume of Freund's adjuvant complete (first injection) or incomplete (second and third injections).

Sequence analyses. The immunocapture reverse transcription polymerase chain

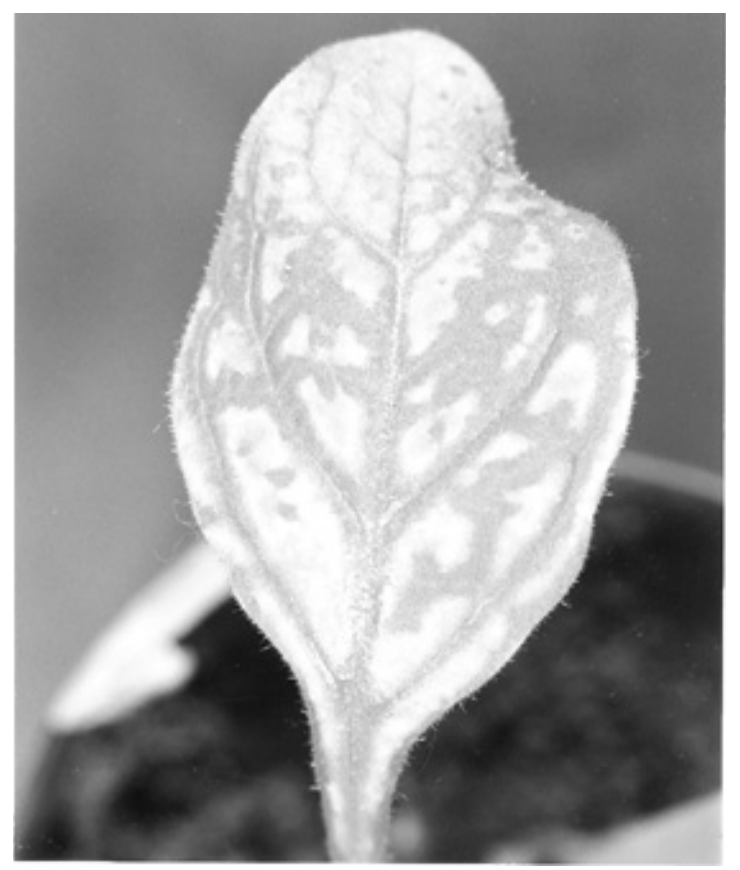

Fig. 1. Leaf of Petunia $\times$ hybrida showing vein banding. 
reaction (IC-RT-PCR) was performed as described previously (12) using an antiserum to Eggplant mosaic virus (EMV) for trapping the virus particles. For amplifying the coat protein gene and the $3^{\prime}$ terminal part of the replicase gene of PetVBV, we used two primers which were derived from parts of the nucleotide sequence of EMV genomic RNA which are more or less conserved in the RNAs of other tymoviruses. EM1 corresponds to nucleotides 5,235 to 5,258 upstream and within the coding region for the RNA-dependent RNA polymerase motif VIII; EM3 is complementary to nucleotides 6,296 to 6,272 in the $3^{\prime}$ untranslated region of EMV genomic RNA. The PCR product was purified from agarose gels using the Jetsorb Gel Extraction Kit (Genomed GmbH, Bad Oeynhausen, Germany) and cloned into the pGEM-T vector (Promega Corp., Madison, WI) for sequencing, which was performed by a commercial company (SeqLab, Göttingen, Germany). Sequences were analyzed by the University of Wisconsin Genetics Computer Group (UWGCG) software, version 8 (5). The gene bank accession number of the partial sequence of PetVBV RNA is AF210709.

\section{RESULTS}

Host range, symptomatology, and transmission behavior. Petunia leaves showing vein banding (Fig. 1) contained
45- and 30-nm virus-like particles. After several unsuccessful attempts, we succeeded once in transmitting the smaller particles by mechanical inoculation to a healthy petunia plant from which they were then further transmitted to petunia, producing local chlorotic and necrotic spots and systemic vein banding. They were also transmitted to Nicotiana benthamiana, producing local necrotic spots and systemic chlorotic mosaic, and to Nicandra physalodes, producing systemic vein clearing and mosaic. These symptoms were observed only during autumn and winter. No infections were obtained on other solanaceous plants (i.e., Capsicum annuum; Datura stramonium; Lycopersi-
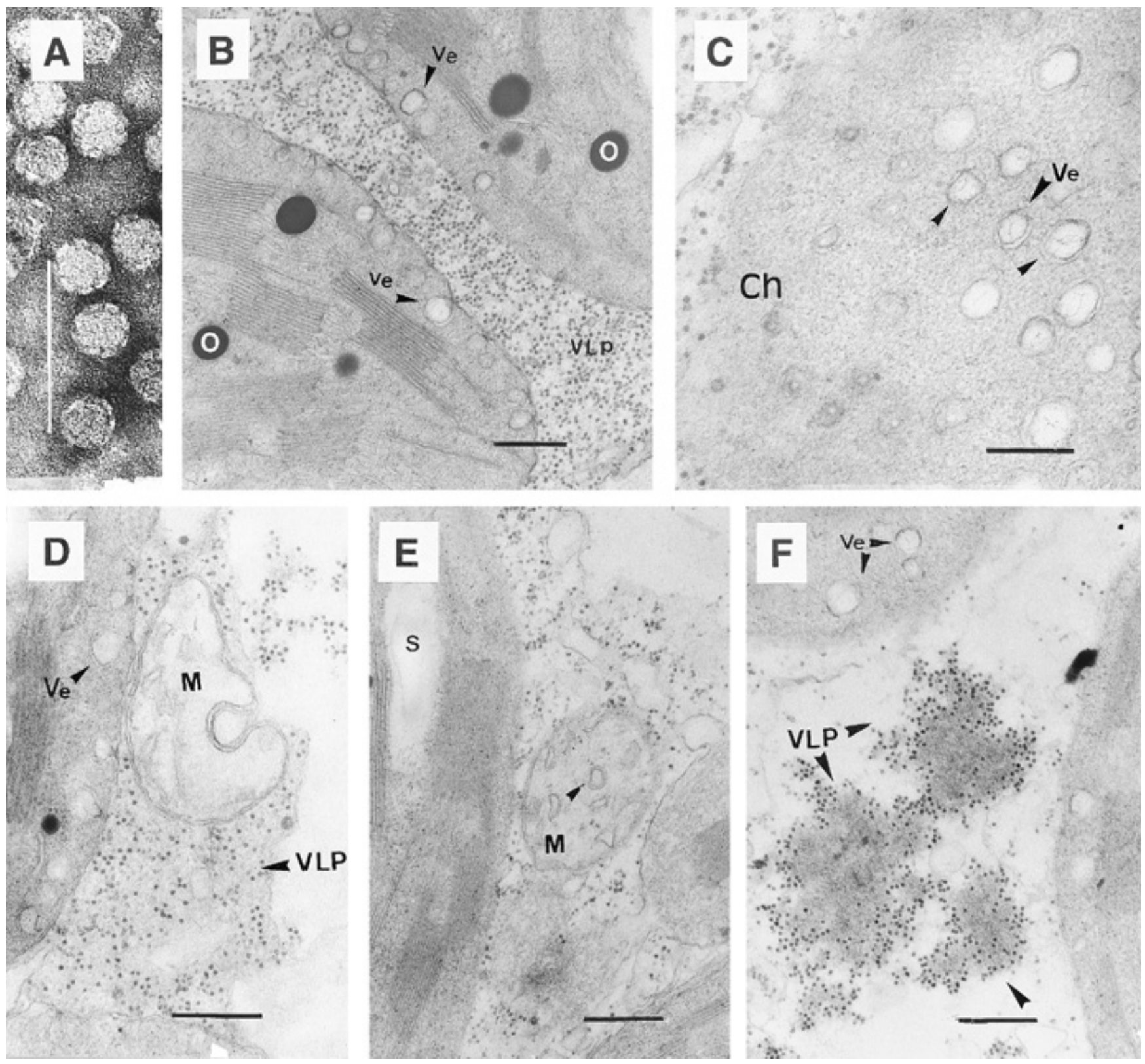

Fig. 2. (A) Electron micrograph of a negatively stained purified Petunia vein banding virus (PetVBV) preparation from Petunia $\times$ hybrida showing particles with clustering of protein subunits. Bar $=100 \mathrm{~nm}$. (B-F) PetVBV-infected mesophyll cells from Petunia $\times$ hybrida. (B) Chloroplasts showing peripheral double-membraned vesicles (arrow head). (C) Tangentially sectioned chloroplast with double-membraned vesicles containing fibrillar material. (D) Distorted mitochondrion close to a chloroplast. (E) Mitochondrion with a double-membraned vesicle. (F) Virus-like particles associated with cytoplasmic dense amorphous masses. $\mathrm{Ch}=$ chloroplast, $\mathrm{M}=$ mitochondria, $\mathrm{O}=$ osmiophilic globules, $\mathrm{S}=$ starch, $\mathrm{Ve}=$ vesicles, and VLP $=$ virus-like particles. $\mathrm{Bars}=$ $300 \mathrm{~nm}$. 
con esculentum "Kada gigante" or "Santa Cruz"; Nicotiana debneyi; N. glutinosa; N. rustica; N. tabacum "Samsun", "TNN", "Turkish", or "White Burley"; Solanum luteum; S. melongena); and 16 other plant species belonging to the families Amaranthaceae, Apocynaceae, Asteraceae, Balsaminaceae, Brassicaceae, Chenopodiaceae, Cucurbitaceae, and Fabaceae.

No seed transmission was observed in tests with 500 seeds each from naturally and experimentally infected petunia plants. $M$. persicae and $A$. gossypii failed to transmit the virus. Transmission by the chrysomelid beetle $D$. speciosa could not be tested because the insects did not feed on petunia and died.

Electron microscopy. In negatively stained preparations of PetVBV, the clustering of coat protein subunits typical of tymoviruses was clearly visible (Fig. 2A). Examination of thin sections from infected leaves revealed remarkable cytopathic effects in chloroplasts comprising peripheral double-membraned vesicles (Fig. 2B) occasionally containing fibrillar material (Fig. 2C). Clumps of somewhat rounded chloroplasts were also noted. Mitochondria were sometimes distorted (Fig. 2D) and showed vesicles (Fig. 2E) similar to those found in chloroplasts. Virus-like particles were observed free in the vacuoles as well as in the cytoplasm and were sometimes associated with electron-dense amorphous masses (Fig. 2F).

Serology. In the agar gel double diffusion test, PetVBV did not react with antisera to Cocoa yellow mosaic virus (CYMV), Clitorea yellow vein virus (CYVV), Desmodium yellow mosaic virus, Okra mosaic virus, Passion fruit yellow mosaic virus, Physalis mottle virus, Plantago mottle virus, Poinsettia mosaic virus, Scrophularia mosaic virus, or Turnip yellow mosaic virus (TYMV), which were all adjusted to a homologous titer of 1:128. Strong reactions were, however, observed with antisera to all viruses of the Andean

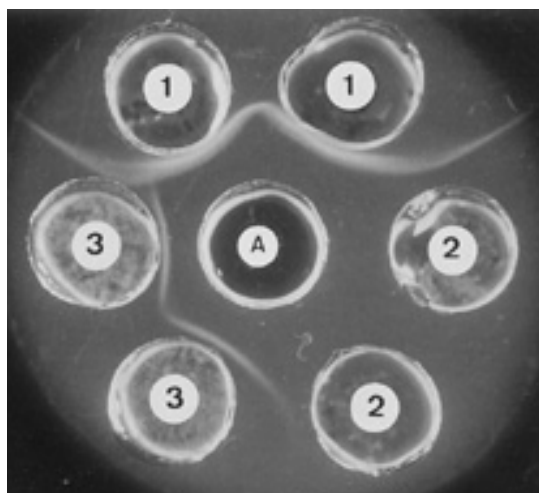

Fig. 3. Agar gel double diffusion test using sap from Petunia vein banding virus (PetVBV)infected (1) and healthy (2) petunia leaves; and Eggplant mosaic virus type-strain from infected Datura spp. leaves (3) in the outer wells and antiserum to PetVBV in the central well (A). potato latent virus (APLV)-EMV cluster $(9,10)$ (i.e., the type, $\mathrm{Al}$, and the tomato strains of EMV and the Col, Col2, Caj, and Ay strains of APLV). However, PetVBV was not identical to any of these viruses, because pronounced spur formation was observed when PetVBV and these viruses were tested in adjacent wells with antiserum to PetVBV (Fig. 3).

Molecular properties. Analyses of the deduced amino acid sequence of the coat protein and of the nucleotide sequence of the 3'-terminal part of the replicase gene of PetVBV both revealed the highest percentages of identity (i.e., $65 \%$ each) with the corresponding sequences of EMV and APLV (Fig. 4A and B). The percentages of sequence identity with other tymoviruses from solanaceous hosts were lower and with those from other hosts (shown in Fig. 4 only for TYMV) were even less. The groupings seen in Figure 4A and B were also confirmed by neighbor joining analyses $(15$; results not shown). The molecular mass of the PetVBV coat protein was calculated to be $19.6 \mathrm{kDa}$.

\section{DISCUSSION}

The host range, serological, molecular, and cytopathological studies described in this article clearly indicate that the virus with 30-nm particles found in petunia is a distinct tymovirus which has its closest relationships to APLV and EMV. This new virus infects only three solanaceous hosts (i.e., Petunia spp. N. benthamiana, and N. physalodes), whereas the various strains of APLV and EMV have much wider host ranges $(6,7,17)$. Also, the two EMV-like viruses described in Brazil, Tomato white necrosis virus (4) and an EMV isolate from tobacco (14), infect hosts belonging to several other families in addition to the Solanaceae family.
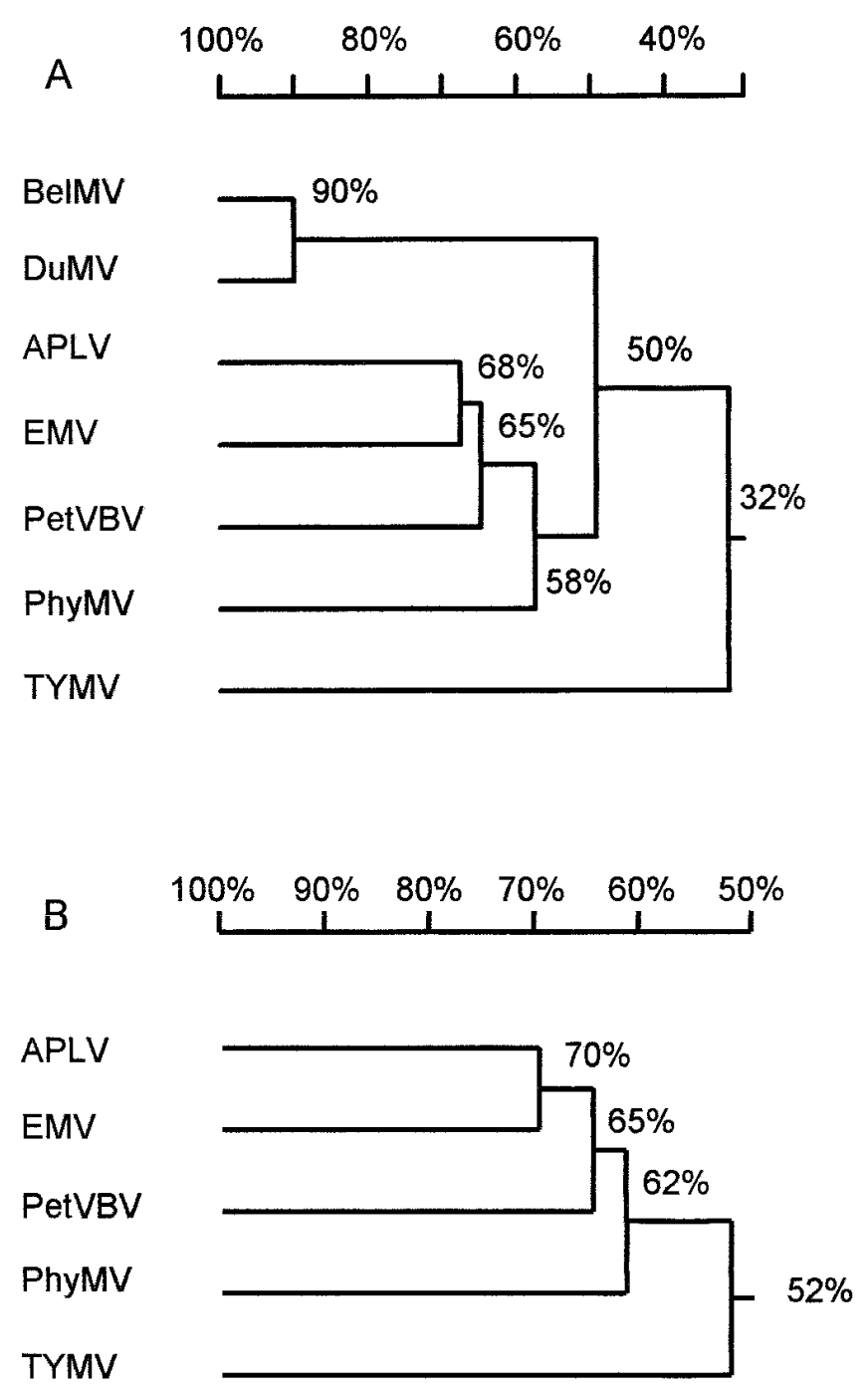

Fig. 4. Percentages of identities in the sequences of (A) the amino acids of the coat proteins and (B) the approximately $3703^{\prime}$-terminal nucleotides of the replicase genes of tymoviruses infecting solanaceous hosts, including Belladonna mottle virus (BelMV; X54529), Dulcamara mottle virus (DuMV; AF035634), Andean potato latent virus (APLV; AF035402), Eggplant mosaic virus (EMV; J04374), Petunia vein banding virus (PetVBV; AF210709), Physalis mottle virus (PhyMV; Y16104), and Turnip yellow mosaic (TYMV; X16378). The respective gene bank accession numbers are given in parentheses. 
PetVBV produces several cytopathic effects typical for tymovirus infections (11); in particular, double-membrane bounded vesicles at the periphery of the chloroplasts. Some more specific alterations were also observed (i.e., distorted mitochondria with vesicles similar to those found in chloroplasts) which have so far been seen only in plants infected with CYVV (13). The presence of particles free in the vacuoles as well as in the cytoplasm and their occasional association with electron-dense amorphous masses had up to now been observed only in CYMV infections (11).

The PetVBV coat protein shows only $65 \%$ amino acid sequence identity with the coat proteins of EMV and APLV, the two tymoviruses to which PetVBV has its closest relationships, serologically as well as on the molecular level. Percentages of coat protein sequence identity below $90 \%$ have been suggested to be an important character for demarcating virus isolates as distinct species in the families Poty- and Geminiviridae (16). Similar considerations should also be applicable to plant viruses in other families and genera, including Tymovirus. The identification of a new virus species is suggested because the sequence identity is far below $90 \%$, as is the case for the coat proteins of PetVBV and its closest known relatives. Further differentiating characters which should be taken into account are stressed in the Guidelines for the Demarcation of Virus Species (16), i.e., the existence of differences in the reactivities with key antibodies, in natural host ranges, in transmission properties, and in pathogenicity, including cytopathogenicity. The properties clearly differentiate PetVBV from other tymoviruses. The most reliable differences would be from nucleotide sequence comparisons for the entire genomes. Percentages of total sequence identity $<85$ are considered sufficient for demarcating poty- and geminiviruses as distinct viruses when supported by the other traits (16). Similar criteria apply to other virus genera. For PetVBV, we analyzed the coat protein gene sequence of the $3703^{\prime}$-terminal nucleotides in the replicase gene This sequence showed only $65 \%$ identity with corresponding sequences in the genomic RNAs of APLV and EMV and even lower percentages of identity with the RNAs of other tymoviruses. Based on an alignment of the genomes of tymoviruses for which the entire nucleotide sequences are known (e.g., EMV, Ononis yellow mosaic virus, Physalis mottle mosaic virus, Chayote mosaic virus, Kennedya yellow mottle virus, Turnip yellow mosaic virus, and Erysimum latent virus), the 3 -terminal sequence of the replicase gene is a fairly conserved region of the tymovirus genome (data not shown). Even lower percentages of sequence identity might be expected in other parts of the genome, such as in the $5^{\prime}$ - and $3^{\prime}$-untranslated regions or in the central part of the replicase gene between the coding sequences for the methyltransferase and helicase domains. Our data support the conclusion that PetVBV should be considered as a distinct tymovirus.

Following the recently published guidelines for the demarcation of virus species (16), PetVBV should be regarded as a distinct virus species. Its coat protein as well as the C-terminal part of its replicase show only about 65 to $70 \%$ amino acid sequence identity with the corresponding parts of EMV and APLV, the two tymoviruses to which PetVBV has its closest relationships-serologically as well as on the molecular level. Sequence identities below 85 to $90 \%$ have been suggested to be indicative for a distinct virus species in the above mentioned guidelines.

\section{ACKNOWLEDGMENTS}

We thank J. Normann for reading the manuscript, S. Vianna for providing pictures, and $\mathrm{M}$. Schütt and B. Quast for excellent technical assistance.

\section{LITERATURE CITED}

1. Alexandre, M. A. V. 1997. Identificação de um Tymovirus isolado de Petunia x hybrida Vilm. com infecção dupla. Ph.D. thesis, Universidade de São Paulo, Brazil.

2. Alexandre, M. A. V., Rivas, E. B., Duarte, L. M. L., and Chagas, C. M. 1992. Ocorrência natural de um tobamovirus em Petunia hybrida. (Abstr.) Fitopatol. Bras. 17:224.

3. Alexandre, M.. A. V., Rivas, E. B., Duarte, L. M. L., Chagas, C. M., and Cardoso, C. P. 1993. Presença de um possível caulimovirus em Petunia hybrida. (Abstr.) Summa Phyto- pathol. 19:48.

4. Barradas, M. M. 1983. Caracterização do vírus da necrose branca do tomateiro (VNBT) e sua identificação como um Tymovirus. Ph.D. thesis, Universidade de São Paulo, Brazil.

5. Devereux, J., Haeberli, P., and Smithies, O. 1984. A comprehensive set of sequence analyses for the VAX. Nucleic Acids Res. 12:387-395.

6. Gibbs, A. J., and Harrison, B. D. 1973. Eggplant mosaic virus. C.M.I./A.A.B. Descriptions of Plant Viruses, 124.

7. Gracia, O, Koenig, R., Feldman, J. M., and Barradas, M. M. 1988. A strain of eggplant mosaic virus causing a severe disease of tomato in Argentina. J. Phytopathol. 121:337345.

8. Hull, R., Shepherd, R. J., and Harvey, J. D. 1976. Cauliflower mosaic virus: an improved purification procedure and some properties of the virus particles. J. Gen. Virol. 31:93-100.

9. Koenig, R. 1976. A loop structure in the serological classification system of tymoviruses. Virology 72:1-5.

10. Koenig, R., Fribourg, C. E., and Jones, R. A C. 1979. Symptomatological, serological and electrophoretic diversity of isolates of Andean potato latent virus from different regions in the Andes. Phytopathology 69:748-752.

11. Koenig, R., and Lesemann, D.-E. 1981. Tymoviruses. Pages 33-60 in: Handbook of Plant Virus Infections and Comparative Diagnosis. E. Kurstak, ed. Elsevier/North-Holland Biomedical Press, Amsterdam, Netherlands.

12. Koenig, R., Lüddecke, P., and Haeberlé, A M. 1995. Detection of beet necrotic yellow vein virus strains, variants and mixed infections by examining single-strand conformation polymorphisms of immunocapture RTPCR products. J. Gen. Virol. 76:2051-2055.

13. Lesemann, D.-E. 1977. Virus group-specific and virus-specific cytological alterations induced by members of the tymovirus group. Phytopathol. Z. 90:315-336.

14. Ribeiro, S. G., Kitajima, E. W., Oliveira, C. R. B., and Koenig, R. 1996. A strain of eggplant mosaic virus isolated from naturally infected tobacco plant in Brazil. Plant Dis. 80:466469.

15. Saitou, N., and Nei, M. 1987. The neighborjoining method: a new method for reconstructing phylogenetic trees. Mol. Biol. Evol. 4:406-425.

16. van Regenmortel, M. H. V., Bishop, D. H. L., Fauquet, C. M., Mayo, M. A., Maniloff, J., and Calisher, C. H. 1997. Guidelines to the demarcation of virus species. Arch. Virol. 142:1505-1518.

17. Waterworth, H. E., Kaper, J. M., and Koenig, R. 1975. Purification and properties of a tymovirus from Abelia. Phytopathology 65:891-896. 